\title{
Penegakan Hukum terhadap Pelaku Tindak Pidana Penipuan Investasi Ilegal Uang Kripto di Perusahaan E-Dinar Coin Cash (EDCCash) Ditinjau dari Undang-Undang No.19 Tahun 2016 Perubahan atas Undang-Undang No.11 Tahun 2008
}

\author{
Gonaricha Amelia* \\ Prodi Ilmu Hukum, Fakultas Hukum, Universitas Islam Bandung, \\ Indonesia. \\ *gonarichaamelia@gmail.com
}

\begin{abstract}
The study of this paper is about law enforcement for perpetrators of crypocurrency invesment fraud in the E-Dinar Coin Cash (EDCCash) companies. Where the phenomenon of cryptocurrency investment has a high profit so that many people are tempted to join, even the activity is widely done illegally. The purpose of this study is to find out how the modus operandi and law enforcement used by the perpetrators of illegal investment fraud in EDCCash companies to trick their victims is reviewed from Law No.19 of 2016 on Changes to Law No.11 of 2008 on Information and Electronic Transactions (ITE). The research method used in this research is a normative juridical method. Based on the results of research and discussions that are summarized in conclusions, the modus operandi of illegal crypto investment fraud in EDCCash companies is to lure profits of $0.5 \%$ every day and $15 \%$ every month, plus special bonuses without risk and also benefits for recruiting members where each member who does so is promised additional bonuses. Law enforcement for perpetrators of illegal investment fraud of kipto money is regulated in Law No.19 of 2016 on Changes to Law No. 11 of 2008 concerning Information and Electronic Transactions which contain criminal sanctions against perpetrators of illegal investment fraud of cryptocurrencies who intentionally and without the right to spread false and misleading news that resulted in consumer losses in Electronic Transactions with a maximum prison sentence of 6 (six) years. And/or a maximum fine of Rp.1.000.000.000,00 (one billion rupiah).
\end{abstract}

Keywords: Fraud, Illegal Investment, Crypto Money.

\begin{abstract}
Abstrak. Kajian Skripsi ini yaitu mengenai penegakan hukum bagi pelaku penipuan investasi ilegal uang kripto di perusahaan E-Dinar Coin Cash (EDCCash). Dimana fenomena investasi ilegal uang kripto memiliki keuntungan yang tinggi sehingga banyak masyarakat yang tergiur bergabung. Adapun yang menjadi tujuan dalam penelitian ini yaitu mengetahui bagaimana modus operandi dan Penegakan Hukum yang digunakan oleh para pelaku penipuan investasi ilegal uang kripto di perusahaan EDCCash untuk mengelabui para korbannya ditinjau dari UU No.19 Tahun 2016 Tentang Perubahan atas UU No.11 Tahun 2008 Tentang Informasi dan Transaksi Elektronik (ITE). Metode penelitian yang digunakan dalam penelitian ini adalah metode yuridis normatif. Berdasarkan hasil penelitian dan pembahasan yang dihasikan kesimpulan, modus operandi pelaku penipuan investasi ilegal uang kripto di perusahaan EDCCash yaitu menjanjikan keuntungan sebesar $0.5 \%$ setiap harinya dan $15 \%$ setiap bulan, ditambah juga bonus istimewa tanpa risiko dan juga adanya keuntungan bagi perekrutan anggota baru dijanjikan bonus tambahan. Penegakan hukum bagi pelaku penipuan investasi ilegal uang kipto diatur dalam UU No.19 Tahun 2016 Tentang Perubahan atas UU No. 11 Tahun 2008 Tentang Informasi dan Transaksi Elektronik yang isinya pemberian sanksi pidana terhadap pelaku penipuan investasi illegal uang kripto yang dengan sengaja dan tanpa hak menyebarkan berita bohong dan menyesatkan yang mengakibatkan kerugian konsumen dalam Transaksi Elektronik dengan Hukuman pidana penjara paling lama 6 (enam) tahun dan/atau denda paling banyak Rp.1.000.000.000,00 (satu miliar rupiah).
\end{abstract}

Kata Kunci: Penipuan, Investasi Ilegal, Uang Kripto 


\section{A. Pendahuluan}

Pada era modern ini, dimana Fenomena perkembangan di bidang teknologi informasi dan komunikasi telah merebak diseluruh wilayah. Salah satunya yang tidak dapat dihindari dan menjadi perhatian banyak kalangan yaitu kemajuan dalam bidang investasi yakni mata uang kripto atau cryptocurrency. . Uang kripto merupakan mata uang digital yang berlaku secara universal dan tidak mengikuti mata uang negara tertentu dan pasar penjualan uang virtual ini sesuai demand dari pengguna nya sehingga kurs dari uang virtual ini sangat fluktuatif. . Menurut Ketua Satgas Waspada Investasi (SWI) Tongam L Tobing mengatakan, platform aset kripto EDinar Coin (EDC) Cash dinyatakan masuk dalam daftar investasi ilegal. Berdasarkan Peraturan Bappebti No.5 Tahun 2019 tentang ketentuan teknis penyelenggara pasar fisik aset kripto, juga dilengkapi dengan Peraturan Bappeti No.7 Tahun 2020 tentang penetapan daftar asset krito yang dapat diperdagangkan dipasar fisik asset kripto bahwa Perusahaan EDCCash ini tidak masuk ke dalam aset kripto yang terdaftar di Badan Pengawas Perdagangan Berjangka Komoditas (Bappebti) Kementerian Perdagangan.

Namun jika kita melihat fenomena yang muncul akhir-akhir ini, Mata uang kripto dijadikan sebagai objek investasi. Tingginya keuntungan yang didapat dari permainan saham investasi uang kripto di dunia membuat masyarakat Indonesia mulai tergiur untuk berinvestasi. Sehingga dampak penggunaan uang kripto ini jika dilihat dari prospek hukum Indonesia dapat memicu bermacam- macam kejahatan yang menimbulkan kerugian, salah satu nya yaitu tindak pidana penipuan investasi ilegal uang kripto.

Mengenai penipuan ini telah diatur dalam KUHP dan untuk penipuan uang kripto tersendiri diatur dalam UU ITE baik dalam UU No.11 tahun 2008 dan diperbaharui dalam UU No.19 tahun 2016 . Salah satu kasus yang terjadi di tahun 2020 yaitu perusahaan E-Dinar Coin Cash (EDCCash), dimana menurut Ketua Satgas Waspada Investasi (SWI) bahwa platform aset kripto E-Dinar Coin (EDC) Cash dinyatakan masuk dalam daftar investasi ilegal. Perusahaan EDCCash ini tidak masuk ke dalam aset kripto yang terdaftar di Bappebti Kementerian Perdagangan. Kerugian yang dialami member penipuan investasi bodong E-Dinar Coin Cash mencapai Rp 285 miliar. Asumsi kerugian itu berdasarkan member yang terdaftar EDCCash yang diperkirakan mencapai 57 ribu. Adapun setiap membernya minimal diminta menyetor Rp 5 juta. Uang itu ditukarkan dengan koin, yaitu sebanyak 200 koin, membayar sewa cloud 1 bulan kedepan dan akumulasi untuk sponsor (upline). Semua membernya menitipkan uang untuk dibelikan koin, akan tetapi koin tersebut tidak bisa dicairkan menjadi uang.

Berdasarkan latar belakang yang telah diuraikan, maka perumusan masalah dalam penelitian ini sebagai berikut: "Bagaimana modus operandi dan penegakan hukum yang digunakan pelaku tindak pidana penipuan investasi ilegal uang kripto di perusahaan (EDCCASH) ditinjau dari UU ITE?". Selanjutnya, tujuan dalam penelitian ini diuraikan dalam pokok-pokok sbb.

1. Untuk mengetahui modus operandi yang digunakan dalam penipuan investasi ilegal uang kripto di perusahaan E-Dinar Coin Cash (EDCCASH)

2. Untuk mengetahui dan memahami penegakan hukum terhadap kasus tindak pidana penipuan investasi ilegal uang kripto di perusahaan E-Dinar Coin Cash (EDCCASH)

\section{B. Metodologi Penelitian}

Penelitian ini menggunakan pendekatan yuridis normatif, dengan spesifikasi penelitiab berupa deskriptif analitis, dan untuk menganalisis data menggunakan metode normatif kualitatif, analisis data kualitatif dapat dilakukan secara simultan dengan proses pengumpulan data, interpretasi data, dan penulisan naratif lainnya, yang nantinya akan menghasilkan kesimpulan. Penelitian ini bermaksud menggambarkan berbagai masalah dan fakta yang berkaitan dengan penegakan hukum pidana pelaku tindak pidana penipuan investasi ilegal uang kripto yang dihubungkan dengan UU ITE . Selanjutnya penelitian dilakukan dengan studi kepustakaan, dimana penulisan ini dibuat dengan berlandaskan pendapat-pendapat atau tulisantulisan para ahli atau pihak-pihak lain yang berwenang dan juga untuk memperoleh informasi baik dalam bentuk ketentuan-ketentuan formal maupun data melalui nahkah resmi yang ada. 


\section{Hasil Penelitian dan Pembahasan}

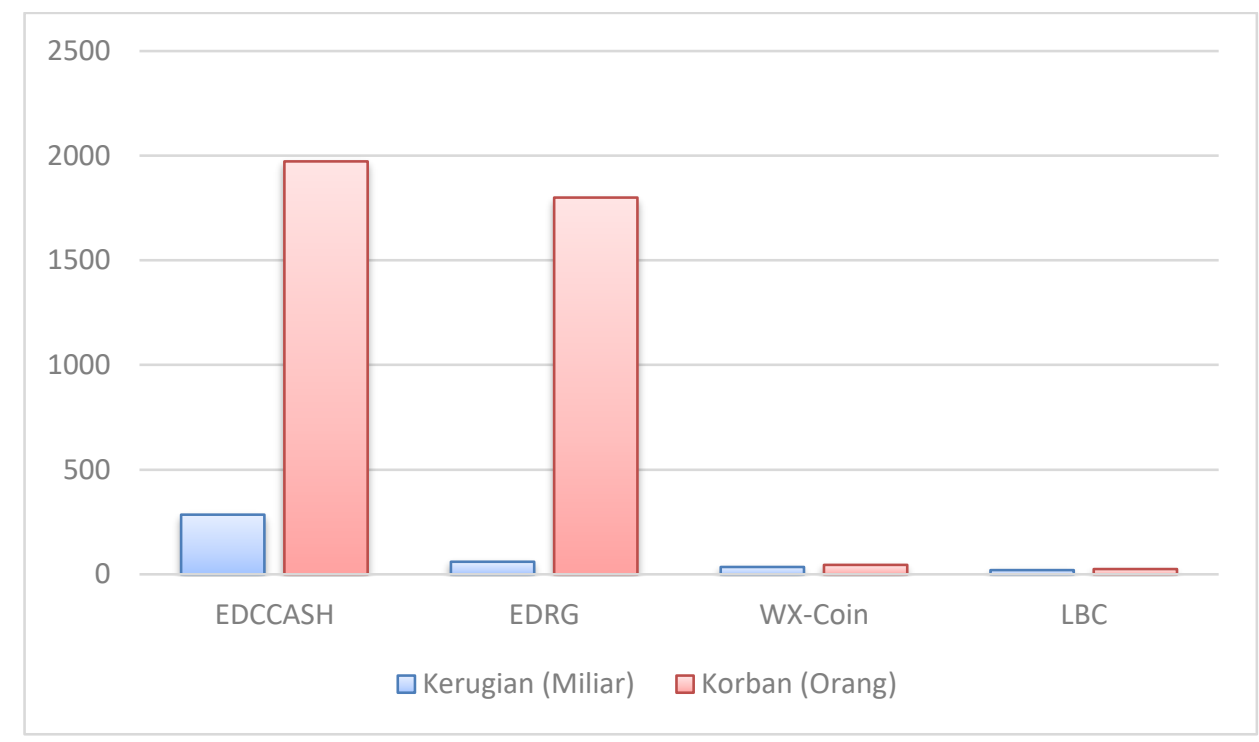

Gambar 1. Praktek Investasi Ilegal Uang Kripto

Sumber: CNN Indonesia Media.com

Sejak akhir tahun 2019 hingga saat ini, investasi aset kripto menjadi buah bibir. Tak sedikit masyarakat yang akhirnya rugi besar karena tergiur iming-iming keuntungan yang menggiurkan dari investasi kripto bodong. Modus yang digunakan investasi kripto bodong tersebut beragam. Ada yang menawarkan bunga per hari, per minggu, hingga membuat sistem multi level marketing (MLM) seperti ponzi.

Sehingga, makin banyak orang yang diajak, semakin besar pula keuntungan yang akan didapatkan. Salah satunya Perusahaan E Dinar Coin Cash, perusahaan ini bergerak di bidang jual beli kripto, tiap 1 E-Dinar Coin (EDC) dihargai senilai Rp13 ribu. Akadnya adalah pihak perusahaan meminjam deposit untuk digunakan menambang (minning). Lalu, secara otomatis, saldo itu akan bertambah setiap harinya. Meskipun demikian, lama kelamaan harganya jatuh sehingga bernilai rendah. Dalam Kasus ini korban yang sudah melaporkan kasus Edccash ke Bareskrim Polri kurang ebih sekitar 1.973 orang dengan kerugian yang ditaksir mencapai Rp. 285 miliar.

Selain Perusahaan EDCCash ada beberapa Perusahaan dengan kasus yang serupa yaitu, yang pertama E Dinar Coin Gold (EDRG), dimana Skema atau sistim EDRG menjalankan bisnis ini, dengan menggunakan sistim skema ponzi. Cara menghimpun dana dari masyarakatnya dilakukan dengan instrumen perdagangan produk seolah-olah merupakan aset kripto, berupa coin digital yang bernama edrg dalam platform edc blockchain dengan janjijanji korban akan diberikan keuntungan sebesar 0,5\% dalam satu hari atau keuntungan 15\% dalam satu bulan. Kerugian member yang melapor dalam perkara ini sejumlah Rp.1,1 Miliar, sedangkan, kerugian seluruh member yang tergabung dalam komunitas edrg ini mencapai Rp.60 Miliar. Sedikitnya ada 3.445 akun member atau masyarakat yang sudah menjadi korban. Para korban tergiur keuntungan dan percaya bahwa coin EDRG telah mendapat pengakuan dari negara.

Yang Kedua yaitu Kasus WX-Coin, adalah cryptocurrency desentralisasi yang menggunakan teknologi peer-to-peer untuk beroperasi tanpa otoritas pusat atau bank; WX Coin ( WORLDX Coin International ) diduga melakukan penipuan kepada nasabah mereka sebanyak Rp 35 Miliar. WX-Coin menawarkan investasi berupa program bitcoin auto system kepada para anggotanya. Adanya pemeringkatan anggota dalam entitas WX-Coin. Untuk memperoleh BV, tiap anggota mesti melakukan prospek dan mampu merekrut orang lain untuk bergabung ke 
WX-Coin.

Dan yang terakhir yaitu Kasus investasi ilegal LBC, merupakan perusahaan ilegal yang menawarkan investasi penjualan cryptocurrency dengan skema member get member yang menawarkan keuntungan hingga 0,5 persen sampai 3 persen per hari. Atau setara 15 persen hingga 90 persen per bulan.. Kasus ini sudah merugikan 10 korban sebelumnya melapor ke OJK NTB senilai Rp3,2 miliar. LBC hanya memiliki izin sebagai pedagang eceran, bukan investasi di perdagangan modal berjangka. LBC ditetapkan sebagai perusahaan investasi ilegal sejak Mei 2021 sesuai dalam lampiran I SP 03/SWI/V/2021 daftar entitas investasi ilegal yang dihentikan.

\section{Modus pelaku tindak pidana penipuan investasi ilegal uang kripto di perusahaan (EDCCASH) ditinjau dari UU ITE}

Investasi online uang kripto terbukti memenuhi rumusan yang terdapat dalam Pasal 1 dan Pasal 2 UU ITE. Hal ini dikarenakan dalam menjalankan aktivitas investasi para pelaku menggunakan media yaitu internet. Modus yang digunakan investasi kripto ilegal melalui media sosial ini sangat beragam, ada yang menawarkan bunga per hari, per minggu. Sehingga, makin banyak orang yang diajak, semakin besar pula keuntungan yang akan didapatkan. Perusahaanperusahaan ini seolah-olah mengelola dana masyarakat dan menginvestasikan ke dalam berbagai jenis investasi, namun pada kenyataannya hanya sekedar money game. Dimana keuntungan yang dijanjikan oleh perusahaan-perusahan ini terbilang tidak masuk akal dan mengiming-imingkan investasi tanpa resiko, padahal semakin tinggi keuntungan maka semakin besar resiko investasi tersebut. Selain itu , modus yang sering digunakan yaitu adanya sebuah skema dalam investasi tersebut.

Salah satunya Skema ponzi, Menurut Chilton bahwa skema ponzi merupakan bagian dari praktek penipuan keuangan yang sangat merugikan kepada investor. Karena keuntungan yang diberikan oleh perusahaan itu berasal dari investor yang baru bergabung dalam investasi tersebut, bukan dari hasil produk atau jenis usaha yang jalaninya. Dengan demikian modus penipuan investasi ilegal uang kripto di Perusahaan E-Dinar Coin Cash menggunakan skema ponzi dimana pada Perusahaan EDCCash menjanjikan dua macam bonus, yakni sponsor dan referensi dengan perincian sebagai berikut:

1. Bonus sponsor diberikan kepada nasabah yang berhasil merekrut anggota baru, yakni dengan nominal Rp700 ribu dan diberikan dalam bentuk koin E-dinar sejumlah 35 koin ke saldo deposit.

2. Bonus referensi diberikan dari hasil mining anggota yang direkrut, yakni sebesar $3 \%$ dari total koin yang dimiliki tiap individu. Dengan demikian, semakin besar deposit, makin banyak bonus referensi yang akan sponsor peroleh.

\section{Penegakan Hukum Pelaku tindak pidana penipuan investasi ilegal uang kripto di perusahaan (EDCCASH) ditinjau dari UU ITE}

Berdasarakan Pasal 378 KUHP yang berbunyi Barangsiapa dengan maksud untuk menguntungkan diri sendiri atau orang lain secara melawan hukum, dengan memakai nama palsu atau martabat palsu, dengan tipu muslihat ataupun rangkaian kebohongan, menggerakkan orang lain untuk menyerahkan barang sesuatu kepadanya, atau supaya memberi hutang maupun menghapuskan piutang diancam karena penipuan dengan pidana penjara paling lama empat tahun. Dengan demikian unsur-unsur yang terkandung dalam Pasal 378 KUHP antara lain:

1. Unsur "barang siapa". Barang siapa adalah siapa saja yang merupakan subjek hukum yang dapat diminta pertanggung jawaban atas suatu peristiwa pidana, sehingga subjek hukum dalam sengketa ini adalah Perusahaan E-Dinar Coin Cash (EDCCash).

2. Unsur "dengan maksud untuk menguntungkan diri sendiri atau orang lain secara melawan hukum". Dalam sengketa ini, Perusahaan EDCCash telah melakukan perputaran uang milik seluruh penggunanya dengan menggunakan skema ponzi yang telah dilarang, selanjutnya Perusahan EDCCash sengaja meminta penggunanya untuk menginvestasikan uangnya melalui paket keanggotaan, namun saat ini Aplikasi yang digunakan Perusahan EDCCash menghilang secara tiba-tiba dengan membawa miliaran uang milik korban. 
3. Unsur "memakai nama palsu atau martabat palsu, dengan tipu muslihat ataupun rangkaian kebohongan". Dalam sengketa ini, Perusahan EDCCash sengaja melakukan rangkaian kebohongan untuk menipu masyarkat dan membujuk pengguna untuk menginvestasikan uangnya sebesar mungkin agar mendapatkan keuntungan yang berlimpah, salah satunya member yang telah menginvestasikan uangnya untuk membeli paket koin kripto ini mendapatkan Bonus sponsor dan bonus referensi, selain itu juga dapat bonus tambahan berbentuk fisik seperti alat transportasi pribadi, hunian,dll.

4. Unsur "menggerakkan orang lain menyerahkan barang sesuatu kepadanya atau supaya memberi hutang maupun menghapuskan piutang". Dalam sengketa ini, Perusahan EDCCash sengaja menggerakkan seluruh pengguna agar mengajak orang lain bergabung dan membeli paket keanggotaan, dengan bujukan akan mendapatkan keuntungan tambahan. Namun sejatinya hal tersebut dilakukan agar dapat mempertahankan kegiatan usahanya, karena apabila tidak ada lagi orang yang bergabung, maka investasi ilegal uang kripto yang dilakukan Perusahan EDCCash akan runtuh.

Bahwa berdasarkan unsur-unsur dalam pasal 378 KUHP telah terpenuhi oleh seluruh tindakan penipuan. Namun, Penggunaan pasal 378 KUHP kurang tepat apabila digunakan untuk menjerat tindak pidana penipuan investasi uang kripto yang terdapat pada dunia maya dengan menggunakan media elektronik sebagai sarana untuk melakukan tindak pidananya, dikarenakan adanya keterbatasan dalam alat bukti yang secara limitiatif dibatasi oleh KUHAP.

Pasal 28 ayat (1) UU ITE tidak secara langsung mengatur mengenai tindak pidana penipuan konvensional maupun tindak pidana penipuan online, tetapi unsur-unsur di dalam pasal 28 ayat (1) UU ITE identik dan memiliki beberapa kesamaan pada tindak pidana penipuan konvensional yang diatur dalam pasal 378 KUHP dan memiliki karakteristik khusus yaitu telah diakuinya bukti, media elektronik, dan adanya perluasan yurisdiksi dalam UU ITE. Unsur-unsur yang terkandung dalam Pasal 28 ayat (1) Undang-Undang ITE yaitu:

1. Unsur "setiap orang". Dalam sengketa ini pelaku usaha Perusahan EDCCash sengaja mempromosikan Perusahan EDCCash sebagai kegiatan usaha di bidang investasi uang kripto yang berbasis daring melalui situs domain Perusahan EDCCash dan aplikasi Perusahan EDCCash, sebagai suatu aplikasi yang dapat menghasilkan uang dengan caracara yang tidak dapat dipertanggungjawabkan secara hukum.

2. Unsur "dengan sengaja dan tanpa hak". Dalam unsur ini terkandung niat jahat dalam perbuatan yang dilakukan, Perusahan EDCCash sengaja membujuk masyarakat untuk menginvestasikan uangnya dalam bentuk coin kripto sebagai modal awal paket keanggotaan, agar pelaku usaha dapat menguasai uang milikmember perusahaan EDCCash.

3. Unsur menyebarkan berita bohong dan menyesatkan. Dalam rumusan unsur pasal ini terdapat kata "dan" yang mengandung arti bahwa kedua unsur yakni unsur "berita bohong" dan "menyesatkan" harus terpenuhi dalam pemidanaan. Perusahan EDCCash sengaja menyebarkan berita bohong dengan menyatakan bahwa Perusahan EDCCash dapat menghasilkan uang dengan cara yang mudah dan cepat, pengguna akan mendapatkan bonus apabia merekrut keanggotaan. Perusahan EDCCash juga menyebarkan kebohongan dengan menyatakan bahwa situsnya telah mendapat izin beroperasi dari OJK dan Bappeti, namun pada praktiknya menurut Peraturan Bappeti No.7 Tahun 2020 tentang penetapan daftar asset krito yang dapat diperdagangkan dipasar fisik asset kripto bahwa Perusahaan EDCCash ini tidak masuk ke dalam aset kripto yang terdaftar di Bappebti Kementerian Perdagangan,

4. Unsur "yang mengakibatkan kerugian konsumen dalam transaksi elektronik". Ketika banyak korban yang merasakan dirugikan dalam investasi uang kripto ini, dimana aplikasi yang digunakan oleh Perusahan EDCCash tiba-tiba tidak dapat diakses lagi oleh korban setelah melakukan penarikan keuntungan yang belum sampai pada jumlah yang dijanjikan. Serta persaksian korban dari perusahaan EDCCash yang diperintahkan untuk melakukan deposit kembali dengan alasan untuk mendongkrak komisi yang akan diperoleh, namun justru kerugian korban semakin bertambah dengan penambahan deposit yang dilakukannya. 
Pembuktian seluruh unsur-unsur Pasal 28 Ayat (1) Undang-Undang ITE telah terpenuhi oleh seluruh tindakan yang dilakukan Pelaku tindak pidana penipuan investasi ilegal di Perusahaan EDCCash. Sanksi pidana pidana dalam Pasal 28 Ayat (1) Undang-Undang ITE diatur berdasarkan Pasal 45 Ayat (1) Undang-Undang ITE dengan ancaman pidana penjara paling lama 6 (enam) tahun atau denda paling banyak Rp. 1 miliar.

Selanjutnya, menurut Pasal 36 UU ITE menjelakan bahwa setiap orang dengan sengaja dan tanpa hak atau melawan hukum melakukan perbuatan sebagaimana dimaksud dalam Pasal 27, yang mengatur bahwa apabila tindakan pelanggaran terkait pasal 27 sampai dengan pasal 34 UU-ITE mengakibatkan kerugian bagi orang lain, maka pasal 36 bisa digunakan. Dalam pasal ini menitikberatkan pada kerugian materiil terjadi pada korban orang khususna, bukan kerugian tidak langsung, bukan berupa potensi kerugian, dan bukan pula kerugian yang bersifat nonmateriil. Sanksi pidana pasal 36 UU ITE ini yaitu Jika melihat dari kasus EDCCash ini bahwa korban memenuhi unsur-unsur dari pasal 36 UU ITE maka sanksi pidana lainnya yang dapat dijeratkan kepada para terangka yaitu terdapat dalam pasal 51 ayat (2) UU ITE dimana Setiap Orang yang memenuhi unsur sebagaimana dimaksud dalam Pasal 36 dipidana dengan pidana penjara paling lama 12 (dua belas) tahun dan/atau denda paling banyak Rp12.000.000.000,00 (dua belas miliar rupiah).

Dalam penerapan hukumannya, langkah-langkah yang telah dilakukan sejauh ini oleh Direktorat Tindak Pidana Ekonomi Khusus (Dittipideksus) Bareskrim Polri pada kasus ini yaitu adalah melayangkan surat panggilan kepada korban guna untuk mendapatkan informasi lebih mendalam lagi terkait kasus tersebut. Untuk mendapatkan identitas pelaku, peran pelaku dalam pelaksanaan kejahatan penipuan investasi, serta melakukan pemeriksaan saksisaksi terhadap kasus penipuan investasi dengan menerapkan skema Ponzi tersebut. Selain itu Dittipideksus juga membuka Layanan pengaduan yang sampai Agustus 2021 yang membuat laporan polisi ada tiga orang, yang menjadi saksi ada 60 orang, dan yang mengadu di layanan aduan ada 1.973 orang. Jaksa penuntut umum (JPU) telah menyatakan berkas perkara kasus investasi bodong EDCCash lengkap. JPU telah memberikan surat P21 terhadap perkara penipuan investasi ilegal uang kripto di perusahaan EDCCash ini.

Dapat disimpulkan bahwa penegakan hukum dapat tercipta dan terlaksana dengan baik jika para penegak hukum dan pihak yang dirugikan dapat bekerja sama dengan baik. Seperti ketika aparat penegak hukum telah membuat suatu strategi atau upaya penegakan hukum yang akan dilakukan, kiranya pihak yang dirugikan dapat disiplin dalam membantu upaya aparat penegak hukum dengan memenuhi panggilan yang dilayangkan oleh aparat penegak hukum secepat mungkin, siap dan dapat memberikan keterangan dengan sebenar-benarnya, serta mempersiapkan diri kembali jika dibutuhkan.

\section{Kesimpulan}

Berdasarkan pembahasan dalam penelitian ini, peneliti menyimpulkan beberapa hasil penelitian sebagai berikut:

1. Praktek Penipuan investasi ilegal pada sekarang ini menjadi marak kembali dengan berbagai modusnya salah satunya cryptocurrency (uang kripto) dengan skema ponzi yang memanfaatkan media online, mencerminkan bahwa masyarakat Indonesia belum sepenuhnya memahami berbagai investasi legal menurut aturan Otoritas Jasa Keuangan (OJK), dan masyarakat Indonesia masih memiliki budaya malas bekerja sehingga mereka menggunakan cara-cara instan untuk mempercayai tawaran investasi yang beredar di media online.

2. Penegakan hukum terhadap praktik cryptocurrecy dengan skema ponzi pada penipuan investasi ilegal di Perusahaan E-Dinar Coin Cash dapat dilakukan melalui substansi Pasal 378 KUHP dan Pasal 28 Ayat (1) jo. Pasal 45 A Ayat (1) Undang-Undang ITE dan Pasal 36 jo. Pasal 51 ayat (1) UU ITE. Penyelesaian sengketa terhadap praktik penipuan uang kripto dalam investasi ilegal E-Dinar Coin Cash dilakukan melalui melakukan pengaduan melalui Kepolisian atas tindakan penipuan dalam transaksi elektronik. 


\section{Acknowledge}

Dalam proses penulisan Spesia ini penulis tidak lepas dari beberapa hambatan dan kesulitan, akan tetapi berkat dorongan dan bantuan dari berbagai pihak maka skripsi ini dapat diselesaikan tepat pada waktunya. Oleh karena itu, penulis banyak berterimakasih kepada Dr. Ade Mahmud S.H, M.H selaku pembimbing penulis yang telah membimbing, mengarahkan dan memberikan dorongan moril kepada penulis, dan juag kepada kedua orang tua tercinta dan tersayang Ayahanda Gunawan dan Ibunda Juju karena atas doa, dukungan, dan kesabarannya yang tidak pernah lelah dalam mendidik dan memberi kasih sayang yang tulus kepada penulis sejak kecil sampai saat sekarang ini.

\section{Daftar Pustaka}

[1] Haris Herdiansyah, Metode Penelitian Kualitatif, Salemba Humanika, Jakarta Tahun 2019, hlm. 180

[2] Nandang Sambas dan Ade Mahmud, Perkembangan Hukum Pidana dan Asas-asas dalam RKUHP, Penerbit Refika Aditama, Bandung, 2019.

[3] Prasetyono,dkk, Fraud In Financial Scams, Credit Card, And Computes: A Bibliometris Approach, Penerbit Adab, Indramayu, November, 2021, hlm 15.

[4] Advenia Elisabeth, "Ini Jurus-Jurus Mengelak dari Investasi Kripto Bodong", Sindonews.com, https://ekbis.sindonews.com/read/463000/178/ini-jurus-jurus-mengelakdari-investasi-kripto-bodong-1624341998, (diakses tanggal 19 desember 2021, pukul 19.00).

[5] Abdullah Sani, "Berkedok Investai Edinar, ASN di Inhu Riau Tipu Warga Hingga 60 Miliar", Merdeka.com, https://m.merdeka.com/peristiwa/berkedok-investasi-edinar-asn-diinhu-riau-tipu-warga-hingga-rp60-miliar.html, (diaskes tanggal 19 desember 2021, pukul 03.00).

[6] Vadhia Lidyana, "Kasus Penipuan Investasi Aset Kripto, Lucky Best Coin Dilaporkan SWI", IDN Times, https://www-idntimescom.cdn.ampproject.org/v/s/www.idntimes.com/business /economy/amp/vadhia-lidyana1/kasus-penipuan-investasi-aset-kripto-lucky-best-coin-dilaporkan-swi? , (diakses tanggal 19 desember 2021, pukul 05.00)

[7] Tim VOI, "Catat Korban Investasi Ilegal EDCCash Sentuh 52 Ribu, Mabes Polri Masih Buka Posko Pengaduan", VOI.com, https://voi.id/berita/77127/catat-korban-investasi-ilegaledccash-sentuh-52-ribu-mabes-polri-masih-buka-posko-pengaduan, (diakses tanggal 03 Januari 2022, pukul 16.00) 